\title{
Growth and physiology of the citrange 'Fepagro C37 Reck' rootstock innoculated with arbuscular mycorrhizal fungi ${ }^{1}$
}

\author{
Marina Martinello Back ${ }^{2 *}$, Gabriela Fedrizzi², Paulo Vitor Dutra de Souza ${ }^{2}$
}

10.1590/0034-737X201865040008

\begin{abstract}
The use of arbuscular mycorrhizal fungi (AMF) in the production of rootstocks is a strategy to promote faster plant growth. However, this response depends on the symbiont species. The objective of this study was to evaluate the influence of different species of arbuscular mycorrhizal fungus (AMF) on the development and physiology of citrange 'Fepagro C37 Reck' rootstock. Four species of AMF were used in the experiment: Scutellospora heterogama, Gigaspora margarita, Glomus etunicatum, and Acaulospora sp., and a control treatment. The experiment was arranged in a randomized blocks design, with 5 treatments, 3 replicates, and 10 plants per plot. Every 15 days, height $(\mathrm{cm})$ and stem diameter $(\mathrm{mm})$ of plants were measured in the nursery. At 330 days, the number of leaves, leaf area $\left(\mathrm{cm}^{2}\right)$, fresh and dry mass of roots and shoot (g/plant), root and shoot reserve content, and AMF colonization were evaluated. The AMF inoculation promoted an accelerated vegetative growth, resulting in greater height and diameter. The fungi also promoted greater absorption of most of the nutrients and increase in all other parameters evaluated. However, no effect was found on the reserve content of the rootstock. Roots were colonized with moderate presence of arbuscules and low presence of vesicles. AMF, regardless of species, influence the development and physiology of the citrange 'Fepagro C37 Reck' rootstock.
\end{abstract}

Keywords: endomycorrhizae; citrus; clonal seedling production; vegetative growth; nutrients; colonization.

\section{RESUMO}

\section{Desenvolvimento e fisiologia do porta-enxerto citrangeiro 'Fepagro C37 Reck' inoculado com fungos micorrízicos arbusculares}

A utilização de fungos micorrízicos arbusculares (FMA) na produção de porta-enxertos é uma alternativa para promover um desenvolvimento mais acelerado às plantas. Entretanto, sua resposta depende das espécies dos simbiontes. O objetivo deste estudo foi avaliar a influência de diferentes espécies de FMA no desenvolvimento e fisiologia do portaenxerto citrangeiro 'Fepagro C37 Reck'. Foram utilizadas quatro espécies de FMA: Scutellospora heterogama, Gigaspora margarita, Glomus etunicatum e Acaulospora sp., bem como um tratamento controle. O delineamento experimental foi de blocos ao acaso de 5 tratamentos, com 3 repetições e 10 plantas por parcela. A cada quinze dias, foi medida a altura (cm) e o diâmetro do caule $(\mathrm{mm})$ das plantas no viveiro. Aos 330 dias, foram medidos o número de folhas, a área foliar $\left(\mathrm{cm}^{2}\right)$, a massa fresca e seca das raízes e da parte aérea $(\mathrm{g} / \mathrm{planta})$, o teor de reservas da raiz e da parte aérea, o conteúdo nutricional da parte aérea e a colonização de FMA. A inoculação de FMA promoveu um crescimento vegetativo acelerado, resultando em maior altura e diâmetro. Além disso, os fungos promoveram às plantas maior absorção da maioria dos nutrientes e em todos os outros parâmetros testados. Contudo, não se observou efeito no teor de reservas do portaenxerto. As raízes foram colonizadas, com moderada presença de arbúsculos e baixa de vesículas. Os FMA, independentemente da espécie, influenciam no desenvolvimento e na fisiologia do porta-enxerto citrangeiro 'Fepagro C37 Reck'.

Palavras-chave: endomicorrizas; citros; produção de mudas; desenvolvimento vegetativo; nutrientes; colonização.

\footnotetext{
Submitted on March $05^{\text {th }}, 2018$ and accepted on July $31^{\text {st }}, 2018$

${ }^{1}$ This work is part of the first author's Master Dissertation. Financial support: CNPq.

2 Universidade Federal do Rio Grande do Sul, Departamento de Horticultura e Silvicultura, Porto Alegre, Rio Grande do Sul, Brazil. backmarina@gmail.com; bibi.fedrizzi@gmail.com; pvdsouza@ufrgs.br

*Corresponding author: backmarina @gmail.com
} 


\section{INTRODUCTION}

Citrus production in Brazil is characterized by a low genetic diversity of rootstocks, making it vulnerable to new diseases (Fochesato et al., 2007). One way to reduce risks is the use of different species/varieties of rootstocks, with different characteristics (Souza et al., 2005; Schäfer et al., 2006).

To achieve diversification, studies are needed to test different species with rootstock potential and that have, for example, resistance to diseases, tolerance to abiotic stresses, and affinity with scion varieties of market interest. In addition, the performance should be analyzed throughout the production cycle, from clonal seedling formation in the nursery, during the initial growth in the orchard, and during the full fruit production (Zaccheo et al., 2012; Gonzatto et al., 2011).

In the state of Rio Grande do Sul, the rootstocks used show low growth rate at the nursery stage because of the low temperatures in the winter. Therefore, the time required for clonal seedling production in the southern region of the country is longer, increasing the production cost and, thus, losing to other regions of Brazil in the competitive market (Souza et al., 2005).

A rootstock with great potential, which has already been used successfully in some orchards of Rio Grande do Sul, is 'Fepagro C37 Reck' [Poncirus trifoliata (L.) Raf. $\mathrm{x}$ Citrus sinensis (L.) Osbeck.]. This is a hybrid with trifoliate orange ( $P$. trifoliata (L.) Raf), the most commonly used rootstock in the southern region, and has its desirable characteristics, as well as showing a faster growth in the nursery (Oliveira et al., 2010; Koller, 2013).

An alternative technique for accelerating plant growth is the inoculation with arbuscular mycorrhizal fungi (AMF). These are organisms that are symbiotically associated with plant roots (Jayme \& Quigley, 2014; Wu et al., 2011a). In this symbiosis, the plant supplies the fungus with energy for growth and reproduction via photosynthesis, and the fungus provides the plant with greater absorption of nutrients beyond the root zone, especially phosphorus (Smith \& Smith, 2011). Other important effects of AMF are the increased plant resistance to attack of pathogens of the root system and water absorption capacity (Goltapeh et al., 2008). Therefore, the symbiosis allows the plant a greater absorption of nutrients and water, which accelerates its growth (Jayme \& Quigley, 2014).

According to Ortas (2012), citrus plants are usually highly responsive to AMF because the root system lacks absorbent hairs. However, Smith \& Smith (2011) pointed out that the response of the plant to mycorrhization depends on several factors; one of them is related to the species of the arbuscular mycorrhizal fungus inoculated, mainly due to compatibility with the host and/or adaptation to the environment.
Thus, the objective of this study was to evaluate the influence of different species of arbuscular mycorrhizal fungi on the growth and physiology of citrange 'Fepagro C37 Reck' rootstock.

\section{MATERIAL AND METHODS}

The study was carried out in two phases. The sowing phase (from sowing and AMF inoculation of plants with $10 \mathrm{~cm}$ in height) was carried out in a greenhouse of the Horticulture and Forestry Department (HFD), Campus of the Faculdade de Agronomia of the Universidade Federal do Rio Grande do Sul (UFRGS), Porto Alegre, RS - Brazil ( $30^{\circ} 29^{\prime} \mathrm{S}$ and $51^{\circ} 06^{\prime} \mathrm{W}$ ). The nursery phase (from pricking out seedlings to 5-L polyethylene bags to the end of the experiment) was conducted in a greenhouse at the Agronomic Experimental Station of the Faculdade de Agronomia of the Universidade Federal do Rio Grande do Sul (EEA / UFRGS, 3005’22 “'S, 51³9’08” W), municipality of Eldorado do Sul, RS - Brazil (Km 146, BR 290).

The seeds of the citrange 'Fepagro C37 Reck' rootstock [P. trifoliata (L.) Raf. x C. sinensis (L.) Osbeck.] were obtained from mature fruits harvested from mother plants grown in the citrus collection of the Experimental Agronomic Station at UFRGS, using the methodology described by Souza \& Schäfer (2006). The seeds were heat treated (soaking in water at $52{ }^{\circ} \mathrm{C}$ for 10 minutes).

The AMF inoculants (Scutellospora heterogama, Gigaspora margarita, Glomus etunicatum, and Acaulospora sp.) used in the experiment were grown in the HFD Laboratory from an initial inoculum obtained from the Inoculant Bank of the same department. The selected AMF species were selected from an initial study by Focchi et al. (2004) who carried out a study on arbuscular mycorrhizal fungi naturally occurring in citrus orchards in Rio Grande do Sul.

The inoculum was produced as follows: four $5 \mathrm{~L}$ pots were filled with sterilized sand and the inoculum of an AMF species was mixed in the upper $4 \mathrm{~cm}$ layer of the sand. After inoculation, 20 corn seeds (Zea mays L.) were planted per pot. The pots remained in the laboratory under artificial light and hand watered for two months. After this time, the sand was homogenized with the remains of corn roots, and the new inoculum originated from this mixture. Finally, the inoculum was stored in refrigerator for better conservation.

In February 2013, the rootstocks were inoculated with the AMF. The seeds of the rootstock were planted in commercial substrate, consisting of peat, charred rice husk, and vermiculite in plastic trays $(60 \mathrm{~cm} \times 40 \mathrm{~cm} \times 10 \mathrm{~cm})$. The substrate was previously autoclaved at $120{ }^{\circ} \mathrm{C}$ ( 1 atm pressure) for one hour, for three times at 24 hour intervals.

The trays were kept on a concrete bench in a protected environment and covered by a protective screen to avoid 
insects that could contaminate the experiment. Each tray contained a treatment with AMF (control and the four AMF species).

The trays treated with AMF inoculum were filled with substrate up to the half of the height; and a layer of $400 \mathrm{~g}$ of inoculum (approx. $2 \mathrm{~mm}$ ) was placed on the substrate layer, completing the tray height with substrate. The tray containing the control plants received no inoculum. Finally, 50 seeds of the rootstock were sown per treatment. Trays were hand watered using a hand irrigator, with $1 \mathrm{~L}$ water per tray every two days.

Seedlings, with an average height of $10 \mathrm{~cm}$ (June 8, 2013), were transferred to the greenhouse at the Experimental Agronomic Station of UFRGS in the municipality of Eldorado do Sul, RS. They were pricked out to 5-L polyethylene bags filled with commercial substrate consisting of eucalyptus bark previously disinfested with $7 \%$ formaldehyde solution. The seedlings were kept in 80 $\mathrm{cm}$-high wooden benches and received drip irrigation twice a day, 5 minutes each, totaling $50 \mathrm{~mL}$ of water volume per day.

The experiment was arranged in a randomized blocks design, with 5 treatments (4 AMF + control), 3 replicates, and 10 plants per plot. Vegetative growth, reserve content, and nutrient content were analyzed in 'Fepagro C37 Reck [P. trifoliata (L.) Raf. x C. sinensis (L.) Osbeck.] rootstock inoculated with four AMF species (Scutellospora heterogama, Gigaspora margarita, Glomus etunicatum and Acaulospora sp.) and a control treatment (noninoculated).

Plant vegetative growth (10 plants per plot) was monitored biweekly, measuring height $(\mathrm{cm})$, from the collar to the apex of the plant with a measuring tape, and stem diameter $(\mathrm{mm})$ with a digital caliper, $1 \mathrm{~cm}$ above the substrate level.

The final height $(\mathrm{cm})$, stem diameter $(\mathrm{mm})$, and leaf number per plant of 10 rootstocks per plot were measured 240 days after pricking out the seedlings. Leaf area $\left(\mathrm{cm}^{2}\right)$ per plant was measured using a leaf area LI-Meter. The fresh root and shoot mass $(\mathrm{g})$ and dry matter of root and shoot $(\mathrm{g})$ were determined after drying the samples in a oven at $65^{\circ} \mathrm{C}$ to constant mass.

Dried shoots and roots were ground, mixing 10 plants per treatment and repetition, from which a $1 \mathrm{~g}$ sample was collected to evaluate reserve content, according to the method described by Priestley (1965) with modifications. Each sample was wrapped in a filter cloth, forming small bags. The bags were weighed before and after digestion for 8 hours, soaked in aqueous solution containing 5\% trichloroacetic acid and 35\% methanol, to extract all components of the plant tissue (carbohydrates, fats, etc.) that were not fibers (cellulose, hemicellulose, and lignin). The difference in mass, before and after the digestion, indicates the percentage of reserves contained. We used 3 replicates for each treatment.

The remaining dry matter from samples of shoots of each treatment, initially ground, was used to determine macronutrients $(\mathrm{N}, \mathrm{P}, \mathrm{K}, \mathrm{Ca}, \mathrm{Mg}, \mathrm{S})$ and micronutrients $(\mathrm{Cu}, \mathrm{Zn}, \mathrm{Fe}, \mathrm{Mn}$ and B) carried out at the Laboratory of Soil and Tissue Analysis of the Facudade de Agronomia UFRGS. The results were analyzed according to the Manual of Fertilization and Liming for the States of Rio Grande do Sul and Santa Catarina (SBCS, 2004).

In the same period, two segments of secondary roots were collected from each plant to evaluate the AMF colonization. The roots were washed with distilled water, cut $1 \mathrm{~cm}$ in length, and stored in FAA (formaldehyde, alcohol, and acetone) for fixation. Then, root segments were collected randomly, 15 per replicate, totaling 45 segments per treatment, and stained with trypan blue to observe AMF colonization and structures in the roots using a microscope.

After staining, the root segments were mounted on glass slides and examined under a microscope to evaluate the presence and intensity of hyphae, arbuscules, and vesicles. The percentage of colonized roots was calculated based on the number of infected segments in relation to the total material analyzed. Hyphal density was graded by assigning 0 for the absence of structures; 1 , for low presence; 2, for moderate presence; and 3, for high presence. The density of vesicles and arbuscules was also graded by a scale from 0 to 3 , where the absence of structures was considered as $0 ; 1$ to 50 structures as $1 ; 51$ to 100 as 2 ; and more than 100 as 3 , according to methodology described by Nemec (1992). The process was repeated three times and trained evaluators were used for greater reliability of the results.

Data were analyzed by ANOVA and means were compared by the Duncan test, at the of $1 \%$ and $5 \%$ of significance level.

\section{RESULTS AND DISCUSSION}

The evaluations over the 240 days post-transplant (DAT) to 5-L pots showed that, regardless of treatment, plants had no statistical difference in height up to approximately 130 DAT, (Figure 1).

From that time, the plants inoculated with Gigaspora margarita, Scutellospora heterogama, and Glomus etunicatum showed an exponential primary growth, nearly quintupling the plant height compared to the noninoculated plants at 240 DAT. Plants inoculated with Acaulospora sp. also showed a similar trend, but not as pronounced as with the other species. Non-inoculated plants had a small increase in height after 150 DAT, stabilized in the last days, and reached average of $21 \mathrm{~cm}$ at 240 DAT. 
The plants of all treatments showed no statistical difference for stem diameter up to 150 days (Figure 2). From this time, the inoculated plants started an exponential secondary growth, similar among all inoculated treatments, reaching twice the diameter compared with the controls at 240 DAT (Figure 2).

There was absence of primary (up to 130 DAT) and secondary (up to 150 DAT) growth, because these periods coincided with the winter in the southern country, with average temperatures ranging from $11.5^{\circ} \mathrm{C}$ to $15^{\circ} \mathrm{C}$, from June to September 2013. For the inoculated plants, besides the effect of temperature, absence of growth in this initial period may have been a consequence of the time required for $\mathrm{AMF}$ to colonize the roots and the substrate. Smith \& Smith (2011) discussed that AMF need time for hyphae to occupy the volume of the pot and establish their structures in the root tissues of the host. It is only from this period onwards that they provide a significant acceleration of the plant growth, as they will aid nutrient and water absorption.

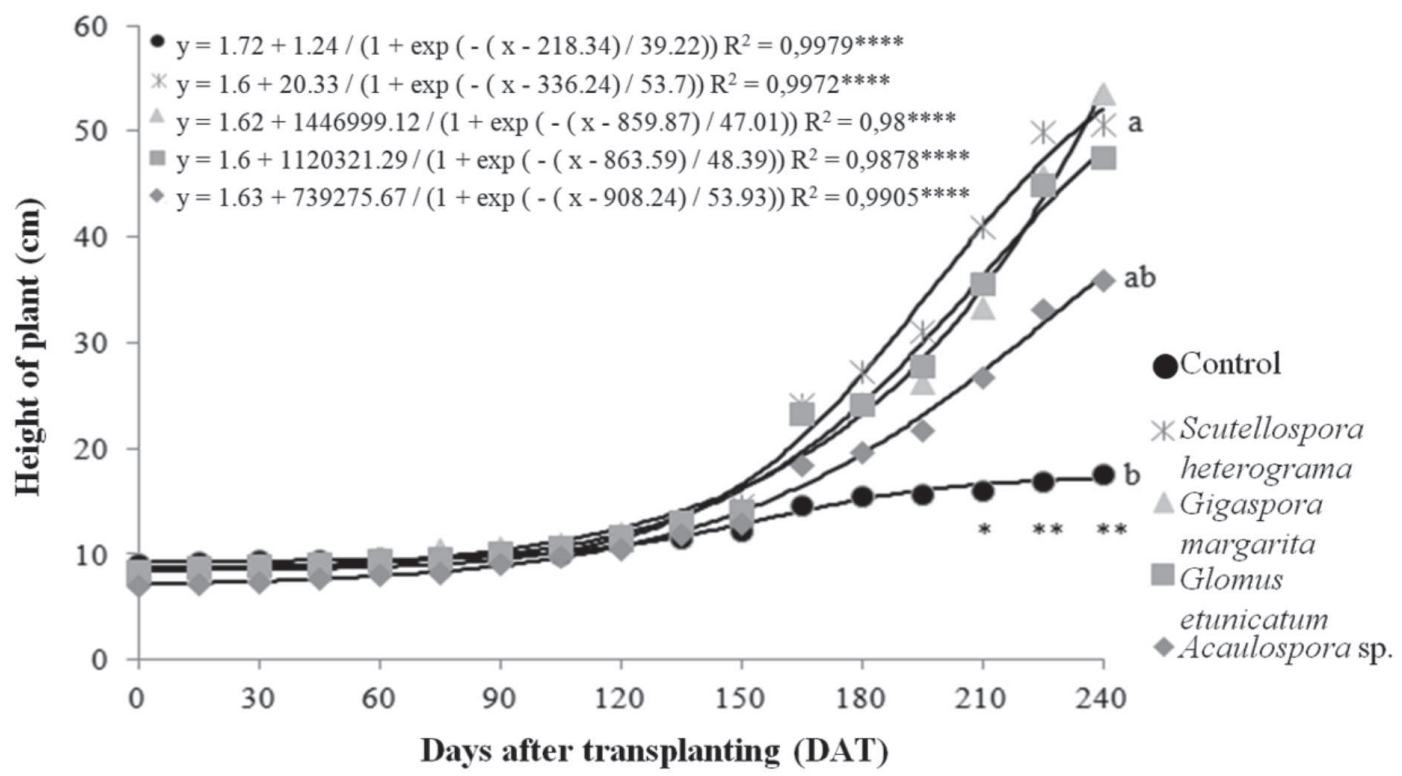

Figure 1: Evolution of the height $(\mathrm{cm})$ of the citrange 'Fepagro C37 Reck' rootstock submitted to the inoculation of arbuscular mycorrhizal fungi during 240 days after transplanting in a greenhouse. **** means $0.01 \%$ significance by the test $\mathrm{F} . *$ and $* *$, mean, respectively, $5 \%$ and $1 \%$ of significance by the Duncan test. Equal lowercase letters do not differ statistically.

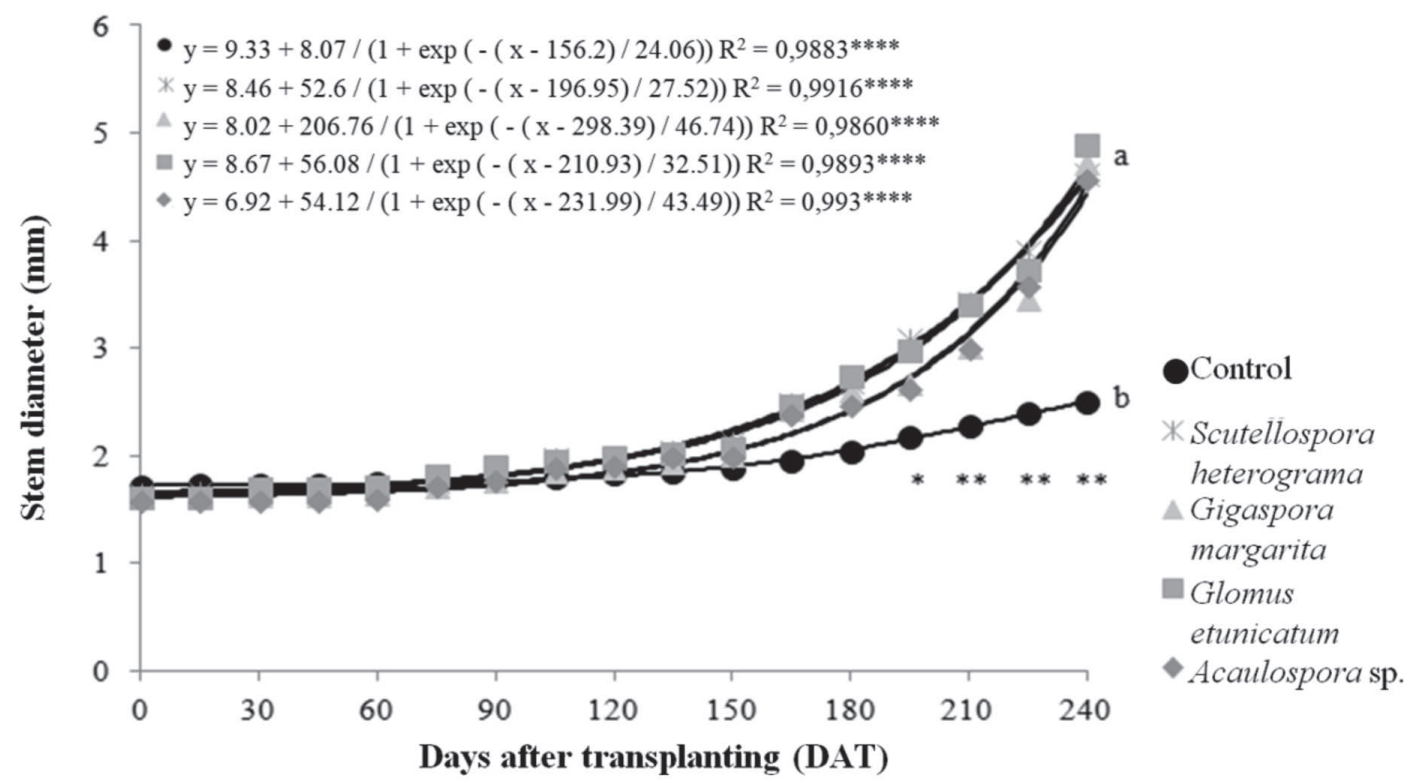

Figure 2: Evolution of stem diameter (mm) of citrange 'Fepagro C37 Reck' rootstock submitted to inoculation of arbuscular mycorrhizal fungi throughout 240 days after transplanting in a greenhouse. **** means $0.01 \%$ significance by the test $\mathrm{F}$ * and $* *$, mean, respectively, $5 \%$ and $1 \%$ of significance by the Duncan test. Equal lowercase letters do not differ statistically. 
The acceleration of plant growth provided by AMF results in a reduction in the time to reach the grafting stage, which may reduce production costs of nurseries. It also allows the production of seedlings within 18 to 22 months, required by Normative Instruction n. 24 of December 16, 2005 (Brazil, 2018), sometimes impossible in southern Brazil, due to the low temperatures in autumn/winter.

In addition to increasing height and stem diameter of citrange 'Fepagro C37 Reck' rootstock, inoculation with AMF, independently of the species, doubled the number of leaves, almost tripled the leaf area, and quadrupled fresh and dried mass of roots and shoot (Table 1 and 2).

There was no significant difference among the AMF treatments for all evaluated parameters regarding the plant vegetative growth. That is, the four AMF species achieved a perfect symbiosis with the host, with nothing affecting the colonization and establishment of their structures in the root system.

The results show a great response of the citrange 'Fepagro C37 Reck' to the presence of AMF in its roots. This is attributed to its root system not having absorbent hairs, a characteristic inherited from one of its parents, Sweet Orange [Citrus sinensis (L.) Osbeck]. This orange has few or no root hairs, organs responsible for the absorption of water and nutrients (Zambrosi et al., 2012, Ortas 2012, Wu et al., 2011b).

These beneficial effects of AMF on several plant species are already known and reported in a number of studies (Costa et al., 2010; Liu \& Wu, 2014; Nunes et al., 2011; Wu et al., 2011b), which found that the fresh mass of roots and shoot was greater in mycorrhizal plants than in non-inoculated plants.

Nunes et al. (2011) observed in their study that the Okinawa peach rootstock inoculated with AMF Glomus etunicatum (Becker \& Gerd) kept in a protected environment showed larger diameter, height, leaf area, fresh and dry mass of the root and shoot than non-inoculated plants. In addition, Back et al. (2016) evaluated the response of the citrange 'Fepagro C37 Reck' to inoculation with Scutellospora heterogama (TH Nicolson \& Gerd.), Gigaspora margarita (Becker \& Hall), Glomus etunicatum (Becker \& Gerd) and Acaulospora sp. and found that the four AMF species provided significant increases in plant height, stem diameter, number of leaves, leaf area, and fresh and dry mass of root and shoot in relation to non-inoculated plants.

Regarding plant nutritional status, Tables 3 and 4 show that AMF also influenced macro and micronutrient levels of the shoot. However, the responses were differentiated, that is, some nutrients had a positive effect, some had negative effect, and others had no effect with inoculation. Among the macronutrients (Table 3), N stands out first, and the relative values were lower than the controls in the plants inoculated with G. margarita and G. etunicatum. The N contents of the plants inoculated with $S$. heterogama and with Acaulospora sp did not differ from the controls.

Table 1: Number of leaves and leaf area ( $\left.\mathrm{cm}^{2} / \mathrm{plant}\right)$ of the citrus rootstock 'Fepagro C37 Reck' submitted to the inoculation of four species of arbuscular mycorrhizal fungi (Scutellospora heterogama, Gigaspora margarita, Glomus etunicatum e Acaulospora sp.)

\begin{tabular}{lcc}
\hline Treatment & Number of Leaves & Leaf Area $\left(\mathbf{c m}^{2} / \mathbf{p l a n t}\right)$ \\
\hline Control & $14.08 \mathrm{~b}$ & $60.536 \mathrm{~b}$ \\
Scutellospora heterogama & $27.76 \mathrm{a}$ & $209.177 \mathrm{a}$ \\
Gigaspora margarita & $25.16 \mathrm{a}$ & $201.880 \mathrm{a}$ \\
Glomus etunicatum & $25.47 \mathrm{a}$ & $180.977 \mathrm{a}$ \\
Acaulospora sp. & $24.02 \mathrm{a}$ & $175.076 \mathrm{a}$ \\
\hline CV $(\%)$ & 14.43 & 22.01 \\
\hline
\end{tabular}

Means followed by the same letter, between rows, do not differ from each other, by the Duncan test, at the $1 \%$ level of significance.

Table 2: Fresh and dry mass of root and shoot (g/plant) of the citrange 'Fepagro C37 Reck' rootstock submitted to the inoculation of four species of arbuscular mycorrhizal fungi (Scutellospora heterogama, Gigaspora margarita, Glomus etunicatum e Acaulospora sp.)

\begin{tabular}{lccrcc}
\hline \multirow{2}{*}{ Treatment } & \multicolumn{2}{c}{ Shoot $(\mathbf{g})$} & & \multicolumn{2}{c}{ Root $(\mathbf{g})$} \\
\cline { 2 - 3 } \cline { 5 - 6 } & FM & DM & & FM & DM \\
\hline Control & $2.570 \mathrm{~b}^{*}$ & $0.770 \mathrm{~b}^{* *}$ & & $2.388 \mathrm{~b}^{* *}$ & $0.841 \mathrm{~b}^{*}$ \\
Scutellospora heterogama & $9.026 \mathrm{a}$ & $3.377 \mathrm{a}$ & & $10.552 \mathrm{a}$ & $3.650 \mathrm{a}$ \\
Gigaspora margarita & $8.314 \mathrm{a}$ & $4.180 \mathrm{a}$ & & $10.920 \mathrm{a}$ & $3.867 \mathrm{a}$ \\
Glomus etunicatum & $8.554 \mathrm{a}$ & $3.337 \mathrm{a}$ & & $8.701 \mathrm{a}$ & $3.446 \mathrm{a}$ \\
Acaulospora sp. & $7.511 \mathrm{a}$ & $2.883 \mathrm{a}$ & & $8.100 \mathrm{a}$ & $3.013 \mathrm{a}$ \\
\hline CV $(\%)$ & 21.89 & 13.24 & & 15.56 & 16.56 \\
\hline
\end{tabular}

Averages followed by the same letter, between rows, do not differ by Duncan's test, at the level of $5 \%(*)$ or $1 \%(* *)$ of significance.

Rev. Ceres, Viçosa, v. 65, n.4, p. 356-363, jul/ago, 2018 
All AMF-inoculated plants had higher $\mathrm{P}$ contents in their tissues compared with controls (Table 3). Among the AMF species, the most efficient in macronutrient accumulation was Acaulospora sp., followed by $G$. margarita, S. heterogama, and G. etunicatum. These results are supported by the literature, since phosphorus is the main nutrient supplied to plants by AMF and it is known for not being mobile in soil and being hardly available to plants (Kiriachek et al., 2009).

The relative values of $\mathrm{K}$ in the tissues were only lower in the plants inoculated with Acaulospora sp., while the other species were not different from the controls. Ca and $\mathrm{S}$ contents were similar between mycorrhizal and control plants. However, the $\mathrm{Mg}$ contents were lower in mycorrhizal plants than the controls, independently of the AMF species.

The mycorrhizal response varied according to the nutrient and AMF species for the relative micronutrient values (Table 4). The plants inoculated with Acaulospora sp and G. margarita had higher percentages of $\mathrm{Cu}$ than the other treatments, which were not different. The $\mathrm{Zn}$ contents were lower in plants inoculated with G. margarita, G. etunicatum and Acaulospora sp, but plants inoculated with $S$. heterogama were not different from the controls.

The concentration of $\mathrm{Fe}$ in the tissues was higher in inoculated plants than in the controls, especially in the presence of G. margarita and G. etunicatum. AMF inoculation resulted in a significant dilution effect on the contents of $\mathrm{Mn}$ in the tissues when compared with the controls. On the other hand, the levels of B were only inferior in the plants inoculated with G. margarita, and no difference was found among the other treatments.

$\mathrm{P}, \mathrm{Cu}$, and $\mathrm{Fe}$ showed the highest relative values in mycorrhizal plants. Similar results were reported by Nunes et al. (2009) and Nunes et al. (2013), who found that $\mathrm{P}$ contents were higher and $\mathrm{Mg}$ were lower in mycorrhizal plants than the controls.

Table 5: Reserve contents of the shoot and root of the citrange 'Fepagro C37 Reck' rootstock submitted to the inoculation of four species of arbuscular mycorrhizal fungi (Scutellospora heterogama, Gigaspora margarita, Glomus etunicatum e Acaulospora sp.)

\begin{tabular}{lcc}
\hline Treatment & Shoot & Root \\
& $\%$ & \\
\hline Control & $33.996^{\text {ns }}$ & $24.197^{\text {ns }}$ \\
Scutellospora heterogama & 32.331 & 18.601 \\
Gigaspora margarita & 32.408 & 13.886 \\
Glomus etunicatum & 33.236 & 15.702 \\
Acaulospora sp. & 31.602 & 18.317 \\
\hline CV $(\%)$ & 8.36 & 20.9 \\
\hline
\end{tabular}

ns Not significant by the Duncan test.

Table 3: Relative content (\%) of macronutrients (nitrogen, phosphorus, potassium, calcium, magnesium and sulfur) of the shoot of the citrange 'Fepagro C37 Reck' rootstock submitted to the inoculation of four species of arbuscular mycorrhizal fungi (Scutellospora heterogama, Gigaspora margarita, Glomus etunicatum e Acaulospora sp.)

\begin{tabular}{|c|c|c|c|c|c|c|}
\hline \multirow{2}{*}{ Treatment } & $\mathbf{N}$ & $\mathbf{P}$ & $\mathbf{K}$ & $\mathbf{C a}$ & Mg & $\mathbf{S}$ \\
\hline & \multicolumn{6}{|c|}{$\%$} \\
\hline Control & $1.40 \mathrm{a}^{* *}$ & $0.50 \mathrm{~d}^{* *}$ & $1.33 \mathrm{a}^{*}$ & $2.70 \mathrm{ab}^{*}$ & $0.29 \mathrm{a}^{* *}$ & $0.37 \mathrm{~ns}$ \\
\hline Scutellospora heterogama & $1.30 \mathrm{ab}$ & $0.54 \mathrm{bc}$ & $1.37 \mathrm{a}$ & $3.03 \mathrm{a}$ & $0.25 \mathrm{~b}$ & 0.33 \\
\hline Gigaspora margarita & $1.23 \mathrm{~b}$ & $0.57 \mathrm{~b}$ & $1.13 \mathrm{ab}$ & $2.60 \mathrm{~b}$ & $0.23 \mathrm{bc}$ & 0.3 \\
\hline Glomus etunicatum & $1.16 \mathrm{~b}$ & $0.53 \mathrm{c}$ & $1.09 \mathrm{ab}$ & $2.43 \mathrm{~b}$ & $0.21 \mathrm{c}$ & 0.31 \\
\hline Acaulospora sp. & $1.43 \mathrm{a}$ & $0.65 \mathrm{a}$ & $1.00 \mathrm{~b}$ & $2.67 \mathrm{ab}$ & $0.21 \mathrm{c}$ & 0.3 \\
\hline $\mathrm{CV}(\%)$ & 3.7 & 2.86 & 13.58 & 5.56 & 7.12 & 6.18 \\
\hline
\end{tabular}

Averages followed by the same letter, between rows, do not differ by Duncan's test, at the level of $5 \%$ (*) or $1 \%$ (**) of significance. ${ }^{\text {ns }}$ Not significant.

Table 4: Relative content ( $\mathrm{mg} / \mathrm{Kg}$ ) of micronutrients (copper, zinc, iron, manganese and boron) of the shoot of the citrange 'Fepagro C37 Reck' rootstock submitted to the inoculation of four species of arbuscular mycorrhizal fungi (Scutellospora heterogama, Gigaspora margarita, Glomus etunicatum e Acaulospora sp.)

\begin{tabular}{lccccc}
\hline Treatment & $\mathbf{C u}$ & $\mathbf{Z n}$ & $\mathbf{F e}$ & $\mathbf{M n}$ & $\mathbf{B}$ \\
\cline { 2 - 6 } & \multicolumn{5}{c}{$\mathbf{~ m g / K g}$} \\
\hline Control & $131.67 \mathrm{c}^{* *}$ & $74.00 \mathrm{a}^{*}$ & $172.33 \mathrm{c}^{* *}$ & $405.00^{* * \mathrm{a}}$ & $48.00 \mathrm{a}^{* *}$ \\
Scutellospora heterogama & $134.00 \mathrm{c}$ & $71.00 \mathrm{a}$ & $230.33 \mathrm{~b}$ & $150.67 \mathrm{~b}$ & $47.00 \mathrm{ab}$ \\
Gigaspora margarita & $177.67 \mathrm{~b}$ & $58.33 \mathrm{~b}$ & $273.67 \mathrm{a}$ & $145.33 \mathrm{~b}$ & $43.33 \mathrm{~b}$ \\
Glomus etunicatum & $144.00 \mathrm{c}$ & $54.33 \mathrm{~b}$ & $291.33 \mathrm{a}$ & $139.00 \mathrm{~b}$ & $45.33 \mathrm{ab}$ \\
Acaulospora sp. & $214.67 \mathrm{a}$ & $54.67 \mathrm{~b}$ & $244.67 \mathrm{~b}$ & $113.67 \mathrm{c}$ & $44.67 \mathrm{ab}$ \\
CV $(\%)$ & 3.5 & 4.61 & 2.8 & 2.82 & 3.2
\end{tabular}

Averages followed by the same letter, between rows, do not differ by Duncan's test, at the level of 5\% (*) or 1\% (**) of significance. 
Table 6: Percentage of colonization, hyphae density and quantification of arbuscules and vesicles in roots of citrange 'Fepagro C37 Reck' rootstock submitted to the inoculation of four species of arbuscular mycorrhizal fungi (Scutellospora heterogama, Gigaspora margarita, Glomus etunicatum e Acaulospora sp.)

\begin{tabular}{lcccc}
\hline Treatment & Colonization $(\%)$ & Hyphae & Arbuscules & Vesicles \\
\hline Control & $9.15 \mathrm{~b} * *$ & $0.312 \mathrm{c}^{* *}$ & $0.271 \mathrm{c}^{* *}$ & $0.005 \mathrm{~b}^{* *}$ \\
Scutellospora heterogama & $100.00 \mathrm{a}$ & $1.625 \mathrm{~b}$ & $1.271 \mathrm{~b}$ & $0.042 \mathrm{~b}$ \\
Gigaspora margarita & $100.00 \mathrm{a}$ & $2.021 \mathrm{ab}$ & $1.958 \mathrm{a}$ & $0.500 \mathrm{a}$ \\
Glomus etunicatum & $100.00 \mathrm{a}$ & $2.229 \mathrm{a}$ & $1.958 \mathrm{a}$ & $0.583 \mathrm{a}$ \\
Acaulospora sp. & $100.00 \mathrm{a}$ & $2.166 \mathrm{a}$ & $1.458 \mathrm{~b}$ & $0.167 \mathrm{~b}$ \\
\hline CV $(\%)$ & 0.27 & 15.66 & 8.92 & 21.45 \\
\hline
\end{tabular}

Means followed by the same letter, between rows, do not differ from each other, by the Duncan test, at the $1 \%$ level of significance.

Reduction in the nutrient contents caused by AMF are attributed to the effects of dilution of the same in the cells caused by a greater absorption of water. In addition, AMF shows a buffer behavior (Anzanello et al., 2011), that is, in condition of high nutrient availability, they absorb only what is needed, for this reason the results of some nutrients such as $\mathrm{Ca}, \mathrm{Mg}$, and $\mathrm{Mn}$ had lower values than noninoculated plants, however, they are already considered high values for plant requirements (SBCS, 2004). Thus, $\mathrm{AMF}$ also has the function of regulating the amount of nutrients absorbed, avoiding greater energy expenditure.

AMF had no influence on the reserve contents of the tissues, ranging from $31.6 \%$ to $34 \%$ in the shoot and $13.9 \%$ to $24.2 \%$ in the roots (Table 5). The effect of AMF on the reserve content of the plants is variable, and there are reports of positive effects (Nunes et al., 2008a; Nunes et al., 2013), null effect (Nunes et al., 2008b), and even negative effects (Souza et al., 2005) attributed to carbohydrate dilution in the cells as the result of the greater vigor and development provided by the AMF.

As for percentage of colonization, all AMF species colonized the roots of the citrange 'Fepagro C37 Reck' rootstock (Table 6). A small contamination was observed in the control plants. This was probably due to the presence of insect such as ants in the experiment, which may have carried spores to these plants (Table 6). However, contamination has also been reported in other studies (Nunes et al., 2008a; Silveira et al., 2006) and had no interfere in the results because it is considered very low and acceptable.

There was variation among the AMF species regarding the hyphal density, especially Glomus etunicatum and Acoulospora sp., with high hyphal density, and Gigaspora margarita with moderate density (Table 6).

Arbuscules are the AMF structures that exchanges nutrients and photoassimilates with plants (Smith \& Smith, 2011). Table 6 shows a considerable amount of arbuscules in the tissues of the roots, characterizing a greater symbiotic activity between the fungus and the plant, explaining the greater vegetative growth of this rootstock.
However, there was a low presence of vesicles in the roots independently of the AMF species (Table 6). Vesicles are globular structures containing granules of glycogen and lipids, thus reserve structures. These structures are formed in periods of low temperature, where there is low activity of the fungus and the host plant (Smith \& Smith, 2011). Because the collection of the roots took place in March, at the end of the summer, there was no need for AMF to accumulate reserves. Typically, in southern Brazil, these structures are formed from April/May (autumn months, with reduced temperature and photoperiod) to provide reserves for the AMF during the winter. These findings were corroborated by studies of Nunes $e t$ al. (2008b) and Nunes et al. (2009), which have similar characteristics to this experiment.

\section{CONCLUSIONS}

Citrange 'Fepagro C37 Reck' rootstock shows a high response to the presence of AMF in its root system for vegetative grow, independently of the species tested;

AMF influence the relative values of macro and micronutrients in the tissues of citrange 'Fepagro C37 Reck' rootstock, including increased percentage of $\mathrm{P}, \mathrm{Cu}$ and $\mathrm{Fe}$;

AMF has no effect on the reserve content of citrange 'Fepagro C37 Reck'.

\section{REFERENCES}

Anzanello R, Souza PVD \& Casamali B (2011) Fungos micorrízicos arbusculares (FMA) em porta-enxertos micropropagados de videira. Bragantia, 70:409-415.

Back MM, Altmann T \& Souza PVD (2016) Influence of arbuscular mycorrhizal fungi on the vegetative development of citrus rootstocks. Pesquisa Agropecuária Tropical, 46:407-412.

Brasil (2018) Ministério da Agricultura, Pecuária e Abastecimento. Instrução Normativa $n^{\circ} 24$ de 16 de dezembro de 2005. Normas para produção, comercialização e utilização de mudas. DOU, 20/12/2005, Seção 1, p.243.

Costa MD, Lovato PE \& Sete PB (2010) Micorrização e indução de quitinases e â-1,3-glucanases e resistência à fusariose em porta-enxerto de videira. Pesquisa Agropecuária Brasileira, 45:376-383 
Fochesato ML, Souza PVD, Schafer G \& Maciel HS (2007) Crescimento vegetativo de porta-enxertos de citros produzidos em substratos comerciais. Ciência Rural, 37:970-975.

Focchi SS, Dal Soglio FK, Carrenho R, Souza PVD \& Lovato PE (2004) Fungos micorrízicos arbusculares em cultivos de citros sob manejo convencional e orgânico. Pesquisa Agropecuária Brasileira, 39:469-476.

Goltapeh EM, Danesh YR, Prasad R \& Varma A (2008) Mycorrhizal Fungi: What We Know and What Should We Know? In: Varma A (Ed.) Mycorrhiza. Heildelberg, Springer. p.03-27.

Gonzatto MP, Kovaleski AP, Brugnara EC, Weiler RL, Sartori IA, Lima JG, Bender RJ \& Schwarz SF (2011) Performance of 'Oneco' mandarin on six rootstocks in South Brazil. Pesquisa Agropecuária Brasileira, 46:406-411.

Jayme B \& Quigley M (2014) Influence of arbuscular mycorrhiza on growth and reproductive response of plants under water deficit: a meta-analysis. Mycorrhiza, 24:109-119.

Koller OL (2013) Citricultura catarinense. Florianópolis, Epagri. 319 p.

Kiriachek SG, Azevedo LC, Peres VEP \& Lambais MR (2009) Regulação do desenvolvimento de micorrizas arbusculares. Revista Brasileira de Ciência do Solo, 33:01-16.

Liu CY \& Wu QS (2014) Relationships between mycorrhizas and antioxidant enzymes in citrus (Citrus tangerina) seedlings inoculated with Glomus mosseae. Pakistan Journal of Botany, 46:1125-1128

Nemec S (1992) Glomus intraradix effects on citrus roostock seedling growth in various potting media. Journal of Agricultural Science, 118:315-323

Nunes JLS, Souza PVD, Marodin GAB \& Fachinello JC (2008a) Inoculação de fungos micorrízicos arbusculares em porta-enxerto de pessegueiro cv Okinawa. Revista Brasileira de Fruticultura, 30:1100-1106.

Nunes JLS, Souza PVD, Marodin GAB \& Fachinello JC (2008b) Incremento no desenvolvimento vegetativo do porta-enxerto de pessegueiro 'Aldrighi' por fungos micorrízicos arbusculares autóctones. Revista Ciência e Agrotecnologia, 32:1787-1793.

Nunes JLS, Souza PVD, Marodin GAB \& Fachinello JC (2009) Eficiência de fungos micorrízicos arbusculares sobre o crescimento do porta-enxerto de pessegueiro 'Aldrighi'. Bragantia, 68:931-940.

Nunes JLS, Souza PVD, Marodin GAB \& Fachinello JC (2011) Incremento no desenvolvimento do porta-enxerto de pessegueiro 'Okinawa', promovido por fungos micorrízicos arbusculares autóctones. Revista Ceres, 58:223-231.

Nunes JLS, Souza PVD, Marodin GAB \& Fachinello JC (2013) Desenvolvimento de plântulas de pessegueiro 'Okinawa' inoculadas com micorrizas arbusculares isoladas de pomares de pessegueiros e de vinhedos. Revista Brasileira de Fruticultura, 35:845852.
Oliveira RP, Soares Filho WS, Passos OS, Scivittaro WB \& Rocha PSG (2010) Porta-enxertos para citros. In: Produção Orgânica de Citros no Rio Grande do Sul. Pelotas, Embrapa Clima Temperado. 295 p.

Ortas I (2012) Mycorrhiza in citrus: growth and nutrition. In: Srivastava AK (Ed.) Advances in citrus nutrition. Amsterdam, Springer. 333-351p.

Priestley GA (1965) A new method for the estimation of the resources of apple tress. Journal of the Science of Food and Agriculture, 16:717-721.

SBCS - Sociedade Brasileira de Ciência do Solo (2004) Manual de adubação e de calagem para os Estados do Rio Grande do Sul e de Santa Catarina. $10^{\mathrm{a}}$ ed. Porto Alegre, SBCS. 400p.

Schäfer G, Souza PVD, Koller OC \& Schwarz SF (2006) Desenvolvimento vegetativo inicial de porta-enxertos cítricos cultivados em diferentes substratos. Ciência Rural, 36:1723-1729.

Silveira SV, Lorscheiter R, Barros IBI, Schwarz SF \& Souza PVD (2006) Mentha piperita as a multiplying of arbuscular mycorrhizal fungi. Revista Brasileira de Plantas Medicinais, 8:9197.

Smith SE \& Smith FA (2011) Roles of arbuscular mycorrhizas in plant nutrition and growth: new paradigms from cellular to ecosystem scales. Annual Review of Plant Biology, 62:227250 .

Souza PVD \& Schäfer G (2006) Produção de mudas de laranjeiras. In: Koller OC (Ed.) Citricultura: 1. Laranja: tecnologia de produção, pós-colheita, industrialização e comercialização. Porto Alegre, Ed. Cinco Continentes. p. 55-87.

Souza PVD, Carniel E, Schmitz JAK \& Silveira SV (2005) Influência de substratos e fungos micorrízicos arbusculares no desenvolvimento vegetativo do porta-enxerto flying dragon (Poncirus trifoliata, var. Montruosa swing.). Revista Brasileira de Fruticultura, 27:285-287.

Wu QS, Zou YN \& Heb XH (2011a) Differences of hyphaland soil phosphatase activities in drought-stress edmycorrhizal trifoliate orange (Poncirus trifoliata) seedlings. Scientia Horticulturae, 129:294-298.

Wu QS, Zou YN \& Heb XH (2011b) Root morphological modification of mycorrhizal citrus (Citrus tangerine) seedlings after application with exogenous polyamines. The Journal of Animal \& Plant Sciences, 21:20-25.

Zaccheo PVC, Neves CSVJ, Stenzel NMC \& Okumura RS (2012) Distribuição do sistema radicular de porta-enxertos sob laranjeira 'Folha Murcha' em clima subtropical. Ciências Agrárias, 33:921-930.

Zambrosi FCB, Mattos D, Furlani RPR, Quaggio JÁ \& Boaretto RM (2012) Eficiência de absorção e utilização de fósforo em porta-enxertos cítricos. Revista Brasileira de Ciência do Solo, $36: 485-496$. 